\title{
39. Better to corrupt plastics than the environment
}

\section{Pippo Ranci}

Plastics have entered the everyday life of humans everywhere and help solve innumerable problems, yet they are a curse on the environment. They remain in the streets and parks and beaches, wherever humans do not dispose of waste properly. This is not an easy exercise for many societies, since it requires an organized and costly system of waste collection, reuse or appropriate incineration. Plastic objects and microplastics are littering the soil and the water, suffocating and poisoning marine life.

Europe is the second largest plastics producer in the world, after China, and out of the 27 million tonnes of plastic waste produced each year in Europe, only a third is recycled. Every year, 150 000-500 000 tonnes of macroplastics and 70 000-130 000 tonnes of microplastics are dumped into the seas around Europe. The majority of these plastics enter the Mediterranean Sea, posing a major threat to marine life. Large plastic pieces injure, suffocate and often kill marine animals, including protected and endangered species, such as sea turtles. The microplastics, smaller and more insidious fragments, have reached record levels in the Mediterranean Sea: their concentration is almost four times higher than in the "plastic island" found in the North Pacific Ocean. Plastic debris in the marine environment contains organic contaminants, of which 78 percent are toxic. By entering the food chain, these fragments threaten an increasing number of animal species as well as human health (Alessi and Di Carlo, 2018).

There are three defence strategies, and they are all necessary:

- reduce the use of plastics in many uses (packaging and wrapping, dishes and cutlery, toys);

- organize reuse or recycling of plastics after use;

- develop production and use of biodegradable or compostable plastics to displace traditional plastics. ${ }^{1}$

We look into the third. 


\section{BIODEGRADABLE, PLEASE, WHEREVER POSSIBLE}

One of the most common uses of plastics is for making containers of all sorts. If these could dissolve at the end of their useful life, the environment would be better. A neat representation of this concept can be found in a few lines written by Primo Levi, a chemist, writer and survivor of the Auschwitz Nazi extermination camp, in his book The Periodic Table. He recounts how some starving detainees in the camp tried to steal anything usable from the lab where they were forced to work, and they could not steal liquids for lack of containers. Here wit and chemistry make the memory of tragedy bearable:

The great problem of packaging, which every experienced chemist knows, was well known to God Almighty, who solved it brilliantly, as he is wont to, with cellular membranes, eggshells, the multiple peel of oranges, and our own skins, because after all we too are liquids. Now, at that time there did not exist polyethylene, which would have suited me perfectly since it is flexible, light and splendidly impermeable: but it is also a bit too incorruptible, and not by chance God Almighty himself, although he is a master of polymerisation, abstained from patenting it: He does not like incorruptible things. (Levi, 1975 [1984], p. 140) ${ }^{2}$

One clarification is necessary. Plastics generally originate from fossil hydrocarbons. Their threat to the environment does not depend on their origin; it depends on the way they are disposed of. Plastic objects and materials pose no threat to the environment if they can be transformed into compost or other useful substances through biodegradation or anaerobic digestion, without substantial emissions. Many, but not all, bioplastics (i.e., plastics from plant material) are biodegradable, and so are a few oil-derived plastics.

Examples of new plastic materials made of agricultural products or by-products can now be found on various websites, such as that of the Ellen MacArthur Foundation. This is a path leading to establishing a circular economy.

\section{OUR SHOPPING SKIN}

One of the first and most successful applications of biodegradable plastics is the shopping bag for food. You buy food and go home, empty the bag and then use it for fruit skins, eggshells and all food scrap and leftovers. Organic waste is easier to collect when it is stored in a compostable bag and the bag itself can be processed (composted) together with its contents. Even if dispersed, these bags will not stay in the environment for long.

The biodegradable shopping bag is now familiar in countries such as France and Italy, thanks to a helping hand from government regulations imposing it or taxing the traditional shopping bag. The cycle could be completed and made 
easier if all food wrappings and price labels were made of biodegradable material: technically, this is quite possible. It would increase the production costs somewhat, while making correct disposal easier and cheaper. A regulatory or tax incentive could provide the impulse, and probably prove economically sound if total costs, rather than mere business costs, were considered.

Further developments are in their early phase in various sectors. Take the introduction of biodegradable dishes and cutlery in catering and in picnic equipment: again, only a matter of direct private costs versus the social cost of the full cycle. Or the introduction of biodegradable plastics into agriculture, given the vast and increasing use of mulching film to keep moisture and nourishment in the ground and facilitate the growth of vegetables and flowers: the black sheets with round holes would last as long as they are useful, then be hoed into the soil and disappear.

The share of biodegradable plastics in all plastics is still minute. Its growth potential is not negligible, but it will not be easy to achieve, since biodegradable plastic is inferior in terms of strength, hardness and tenacity. An overall replacement of traditional plastics cannot be imposed, and a piecemeal replacement calls for a mix of selective obligations and incentive measures. Its success will depend on compliance by, and persuasion of, small farmers, artisans and consumers: a set of decentralized small decisions. One chapter of this story is the many lives of a firm in Italy.

\section{MANY LIVES OF A FIRM}

Montecatini is an attractive small medieval town near Florence, turned into a spa for its thermal springs. In 1888, its name was given to a new company mining copper and sulphur in the nearby hills. Montecatini became the largest chemical company in Italy.

In 1966, it was taken over by Edison, a company that had pioneered electricity in Italy since 1881 and found itself without a mission but rich in cash, after the Italian government had nationalized electricity in 1962. The new company Montedison had a difficult life. In 1986, Raul Gardini, the strong man of the Ferruzzi family, took control as a step in his campaign to build an industrial empire out of the family's agricultural origins. Then he became involved in risky finance and there were stories of corruption, but his passion for marrying agriculture to the chemical industry left a durable mark in the company.

Old Montecatini had left a precious heritage in its research department in Novara, near Milan, where Giulio Natta had discovered isotactic polypropylene, awarding him a Nobel Prize in 1963. In the Novara site, a spin-off lab was set up in 1989 to develop chemicals made of renewable raw materials from agriculture, and then established as a company named Novamont. 
Skilfully managed by chemical scientist Catia Bastioli, Novamont grew into a leader in the new market of biodegradable bioplastics. Since 1990, their Mater-Bi, a bioplastic material produced out of starch, vegetable oils, sugar and other inputs, has enabled compostable shopping bags to displace traditional plastic bags in food shops in Italy and other European countries, and biodegradable mulch film to compete with traditional plastic film for agricultural use in Europe and in North America. Disposable carrier bags are "a kind of waste that presents extremely critical issues", hence the interest in "transforming [them] into an opportunity" (Bastioli, 2013).

Novamont's ambitions go far beyond shopping bags. The company is trying to increase the renewable content of Mater-Bi. It is also developing a variety of materials in the Mater-Bi family, such as biolubricants, biochemicals and cosmetic ingredients (whose flow of polluting microplastics into the water system could be eliminated). Other innovative products made from Mater-Bi belong to the categories of food service and packaging: multi-layer compostable film can combine compostability and gas-barrier properties. Now Novamont is a worldwide company, operating through own distributors in more than 40 countries all over the world.

Its activities are expanding into the exploitation of marginal land and of deindustrialized areas, building an integrated agro-industrial bioeconomy without subtracting agricultural land to food production, using compost as an organic soil improver, and introducing new compostable herbicides that will displace the toxic ones. Together with Turin Polytechnic and the Bologna University, Novamont has set up a new foundation with the purpose of experimenting with techniques for soil revitalization in arid or even sterile areas.

\section{NEW PATHS IN BIOCHEMISTRY}

An article published in the world-level scientific journal Nature illustrates research under way to depolymerize PET (polyethylene terephthalate, one of the most abundant plastic materials) and make it easily recyclable (Tournier et al., 2020). The French green chemistry firm Carbios, set up in 2011, along with the Toulouse Biotechnology Institute, succeeded in finding an enzyme in leaf compost that performs very efficiently in a most valuable operation and which could provide a way out from the present plastic waste nightmare.

Similar biochemical solutions for many types of plastic materials are the object of a massive research effort by many companies worldwide. Since 2017, Carbios itself linked up with large consumers of plastic bottles (such as soft-drinks producers) and with Danish chemical company Novozymes specializing in enzymes, so that its pathbreaking innovations are headed for large-scale production and utilization. 


\section{NOTES}

1. We shall use "compostable" as a synonym for "biodegradable", although some compostable materials do not biodegrade naturally but only under appropriate conditions.

2. I owe this citation from Levi to Catia Bastioli's preface in her handbook (Bastioli, 2014).

\section{REFERENCES}

Alessi, E. and G. Di Carlo (2018), Out of the Plastic Trap: Saving the Mediterranean from Plastic Pollution, Rome: WWF Mediterranean Marine Initiative, accessed 18 August 2020 at http://awsassets.panda.org/downloads/a4_plastics_med_web.pdf.

Bastioli, C. (2013), Speech at the 'Bioplastics: a case study of bioeconomy in Italy in the light of Horizon 2020' conference, at the European Parliament, Brussels, 6 March.

Bastioli, C. (2014), Handbook of Biodegradable Polymers, Shrewsbury, UK: Smithers Rapra Technology.

Levi, P. (1975 [1984]), The Periodic Table [originally published as Il Sistema periodico], New York: Schocken Books.

Tournier, V., C.M. Topham and A. Gilles et al. (2020), “An engineered PET depolymerase to break down and recycle plastic bottles", Nature, 580, 216-19. 